\title{
Phytochemical Screening and Nutritional Analyses of Some Edible Parts of Dioscorea bulbifera $\mathrm{L}$.
}

\author{
MUSADIQ HUSSAIN BHAT $^{1 *}$, MUFIDA FAYAZ $^{1}$, \\ AMIT KUMAR $^{2}$ and ASHOK KUMAR JAIN ${ }^{2}$ \\ ${ }^{1}$ School of Studies in Botany, Jiwaji University, Gwalior-474011, India \\ ${ }^{2}$ Institute of Ethnobiology, Jiwaji University, Gwalior-474011, India \\ musadiqali131@gmail.com
}

Received 1 August 2018 / Accepted 3 September 2018

\begin{abstract}
The present study was aimed to carry out the preliminary phytochemical screening and determine nutritive value, mineral and heavy metal contents in bulbil and tuber extracts of Dioscorea bulbifera L. belonging to family Dioscoreaceae. The dried plant parts were subjected to successive Soxhlet extraction using solvents of increasing polarity such as petroleum ether, chloroform, methanol, ethanol and aqueous. All the extracts were subjected to qualitative phytochemical screening and it showed the presence of active constituents such as alkaloids, saponins, flavonoids, steroids and terpenoids. The mineral analysis of D. bulbifera revealed that it may act as a good source of diet as it contains good amounts of necessary mineral elements, fats, proteins and sugars essential for human health. Heavy metals and inorganic elements were determined by atomic absorption spectrometry technique. The results obtained shows that the levels of three potentially toxic heavy metals analyzed were quite below the permissible limits in both the plant parts analyzed. This justifies its use in the traditional medicine for the treatment of different diseases and as a potential source of alternative food.
\end{abstract}

Keywords: Dioscorea bulbifera, Bulbil, Atomic absorption spectroscopy, Heavy metals

\section{Introduction}

Plant resources have been utilized for the well-being of mankind ever since the dawn of civilization. Of the 2,50,000 higher plant species on earth, more than 80,000 are medicinal ${ }^{1}$. World Health Organization has estimated that about $80 \%$ of the world's population rely mainly on traditional medicines to meet their primary health care needs. Pharmacological screening of natural compounds has been the source of numerous therapeutic agents. Random screening for discovering new biologically active molecules has been most useful in the field of antibiotics ${ }^{2}$. The medicinal value of plants is because of the presence of certain 
classes of chemical constituents that bring a specific physiological effect on the human body. The most important of these bioactive constituents of plants are alkaloids, flavonoids, tannins and phenolic compounds ${ }^{3}$. An active component in a plant is responsible for a particular clinical efficacy. Plants contain a large number of chemical constituents that act together in complex ways to produce the therapeutic effect of the medicine.

Medicinal plants are found to contain minerals and heavy metals which in turn play an important role in their usage. Minerals are the product of geological processes ${ }^{4}$, very essential in the regulation of metabolic process of the body ${ }^{5}$. On the other hand heavy metals are dangerous to the health. World Health Organization guidelines also claim that medicinal plants might be checked for the presence of heavy metals ${ }^{6}$. Therefore, estimation of minerals and heavy metals acquire great importance with respect to the safe and correct use of the plant.

Nowadays, the attention towards biochemical analysis of medicinal plants is on the rise due to the progressing developments in nutrition and mineral prospecting. Macro, micro and trace elements are recognized to play a key role in biological functions in plants and in human metabolism. Furthermore, trace elements play a vital role in the bioactive chemical constituent formation in medicinal plants which are responsible for their medicinal properties ${ }^{7}$.

The members of the genus Dioscorea are one of the oldest crops collected from wild in the tropical regions of the world and comprise one of the important food items for several ethnic groups.

Dioscorea bulbifera L., a glabrous non spiny annual climber is one of the unique medicinal plants among 600 species of family Dioscoreaceae. It is used to treat various ailments in different systems of medicine. In India tubers are used to treat piles, syphilis, dysentery, ulcers and inflammation ${ }^{8}$. It possesses anthelmintic, aphrodisiac and diuretic properties. It is also used in diabetes, gonorrhoea and leprosy ${ }^{9}$. Bulbils are more important food product. It is used in the treatment of rheumatis and arthritis ${ }^{10}$. The tubers are edible, sweet, tonic and antidiabetic. They are also used in heart disease ${ }^{11}$. It is distributed in forests, mixed forest margins, thickets, riverbanks and along valleys up to $1600 \mathrm{~m}$ (a.s.l). It is used as food and it is a good source of calories and minerals such as iron, calcium and phosphorous. Preliminary phytochemical screening of the plants is an important aspect to find out the chemical constituents in plant materials. Hence, the present study was aimed for qualitative analysis of phytoconstituents, heavy metals and inorganic elements present in some edible parts of Dioscorea bulbifera using different methods.

\section{Experimental}

The tubers and bulbils of D. bulbifera $\mathrm{L}$. were collected from Budhi Chanderi, Ashok Nagar (M.P), India. The plant was identified at the Institute of Ethnobiology Herbarium, Jiwaji University Gwalior where a voucher specimen was deposited. The voucher number of the specimen is IOE-451.

\section{Chemicals}

The chemicals used were procured from SRL, Mumbai, India and HI-MEDIA Pvt. Ltd., Bombay. All the chemicals used were of analytical grade.

\section{Preparation of the extracts}

The bulbils and tubers of Dioscorea bulbifera were washed with tap water, shade dried at room temperature and powdered by an electrical blender. From each sample, $5 \mathrm{~g}$ of the plant materials were extracted with $100 \mathrm{~mL}$ of each solvent (petroleum ether, chloroform, 
methanol, ethanol and aqueous) for $8 \mathrm{~h}$ in a Soxhlet apparatus. The crude plant extracts were evaporated to dryness using rotary vacuum evaporator. Extracts were subjected to various qualitative tests for phytochemical screening.

Qualitative phytochemical analysis

The plant samples were assessed for the presence of the various phytochemicals by using the following standard methods:

\section{Test for alkaloids (Mayer's Test)}

Solvent free extract $(50 \mathrm{mg})$ was stirred with $2 \mathrm{~mL}$ of dil. hydrochloric acid $(\mathrm{HCl})$ and filtered. A drop of Mayer's reagent was added to $1 \mathrm{~mL}$ of filtrate by the side of tube and then observed for the formation of a white creamy precipitate.

\section{Test for carbohydrates (Molish's test)}

Few drops of Molish's reagent were added to $2 \mathrm{~mL}$ of the extract followed by addition of $2 \mathrm{~mL}$ conc. $\mathrm{H}_{2} \mathrm{SO}_{4}$ by the side of the test tube. The mixture was then allowed to stand for 2-5 minutes. Formation of a red or violet colour at the inter phase of the two layers indicates the presence of carbohydrates.

\section{Test for flavonoids}

$2 \mathrm{~mL}$ of extract was treated with few drops of $20 \% \mathrm{NaOH}$ solution. Formation of deep yellow colour, which becomes colourless on adding dil. hydrochloric acid, gives the indication of the presence of flavonoids.

\section{Test for glycosides (Legal's test)}

$2 \mathrm{~mL}$ of extract was treated with pyridine and sodium nitroprusside, a blood red colour appearance gives the confirmation for presence of glycosides.

\section{Test for phenols}

A small quantity of the extract was treated with aqueous $5 \%$ ferric and observed for formation of deep blue or black colour.

\section{Test for proteins and amino acids (Million's test)}

The extract $(100 \mathrm{mg})$ was dissolved in $10 \mathrm{~mL}$ of distilled water and filtered through filter paper (Whatman no.1). To $2 \mathrm{~mL}$ of filtrate, few drops of Million's reagent were added and white precipitate formation was observed.

\section{Test for saponins (Foam test)}

To $2 \mathrm{~mL}$ of extract was added $6 \mathrm{~mL}$ of water in a test tube. The mixture was then shaken vigorously and observed for the formation of persistent foam that confirms the presence of saponins in the samples.

\section{Test for steroids (Liebermann Burchard test)}

When $2 \mathrm{~mL}$ of the each extract was dissolved in $2 \mathrm{~mL}$ of chloroform and then treated with concentrated sulphuric acid and acetic acid, development of a greenish colour indicates the presence of steroids.

\section{Test for tannins (Alkaline reagent test)}

Test solution after treatment with sodium hydroxide solution showed yellow to red precipitate within very less time. 


\section{Test for terpenoids}

$2 \mathrm{~mL}$ of chloroform was added to $5 \mathrm{~mL}$ of each plant extract and evaporated on the water path and then boiled with $3 \mathrm{~mL}$ of concentrated $\mathrm{H}_{2} \mathrm{SO}_{4}$. A greyish colour formation confirms the presence of terpenoids.

\section{Determination of nutritive value}

The quantitative estimation of carbohydrates, proteins and fats was carried out using dried material $(100 \mathrm{~g})$. Fats, proteins, carbohydrates were determined by standard protocols ${ }^{12}$. The total nitrogen content was determined using the Kjeldahl method ${ }^{13}$.

\section{Quantitative estimation of heavy metals and inorganic elements Instrumentation}

AAS instrument (Perkin Elmer A Analyst 700 model AAS) with deuterium background corrector was employed for the determination of $\mathrm{K}, \mathrm{Mg}, \mathrm{Ca} \mathrm{Na} \mathrm{Fe}, \mathrm{Zn} \mathrm{Cu}$ and $\mathrm{Mn}$. $\mathrm{As}, \mathrm{Pb}$ and $\mathrm{Hg}$ were determined by HGA graphite furnace using highly pure argon. Other measurements were carried out in an air/acetylene flame. The operating parameters for working elements were set according to the manufacturer recommendations.

\section{Dry ashing procedure}

One gram of sample was transferred into a porcelain crucible. The muffle furnace temperature was gradually increased to $450{ }^{\circ} \mathrm{C}$ in $1 \mathrm{~h}$. The sample was dried for $1 \mathrm{~h}$ in the oven, cooled and reweighed. The obtained sample was ashed for about $8 \mathrm{~h}$ until a gray or white ash residue was obtained. The residue was dissolved in $5 \mathrm{~mL}$ of $\mathrm{HNO}_{3}(25 \%, \mathrm{v} / \mathrm{v})$. Then the digestion solution was heated using an electric hot plate at $150{ }^{\circ} \mathrm{C}$ until evaporated to near dryness. The residue was then filtered through Whatman filter paper and transferred into a volumetric flask and made up to $25 \mathrm{~mL}$ volume by adding $3 \% \mathrm{HNO}_{3}$. The blank digestion experiment was also prepared in the same way ${ }^{14}$.

\section{Analytical procedure}

AAS is a widely used technique for determining a large number of metals. In AAS, an aqueous sample containing the metal analyte of interest is aspirated into an air-acetylene flame, causing evaporation of the solvent as well as vaporization of the free metal atoms (atomization). K, Mg, Ca Na Fe, $\mathrm{Zn}, \mathrm{Cu}$ and $\mathrm{Mn}$ in Dioscorea bulbifera L. samples (tubers and bulbils) were analyzed using AAS equipped with flame and graphite furnace. Graphite furnace was used for the determination of trace and ultra-trace concentrations $(\mathrm{Pb}, \mathrm{As}, \mathrm{Hg})$. The following solutions ( $\mathrm{La}(\mathrm{III})$ ions when determining $\mathrm{Mg}$ or $\mathrm{Ca}$ and $\mathrm{CsCl}$ solutions were used as an ionization buffer in measurements of $\mathrm{K}, \mathrm{Mg}$ and $\mathrm{Na}$ and were added to both sample and standard solutions in order to overcome chemical interferences in the flame upon determination $^{15}$. Data were rounded off properly based on the value of standard deviation from measurement conducted in triplicate.

\section{Results and Discussion}

\section{Preliminary qualitative phytochemical analysis}

The results of qualitative phytochemical analysis are presented in the Tables 1 and 2. The Phytochemical screening in the present study has revealed the presence of alkaloids, carbohydrates, glycoside, phytosterols, saponins, tannins, phenols, flavonoids, proteins, amino acids, terpenoids. Alkaloids were found present in all extracts of both the plant parts 
of D. bulbifera. Results revealed that both screened parts showed presence of proteins, amino acids, phenols and carbohydrates in all the extracts except petroleum ether. Flavonoids were detected in all bulbil extracts. However in tuber, except petroleum ether extract all the extracts showed positive results. Only methanol, ethanol and chloroform extracts of bulbil were tested positive for the presence of glycosides. While as glycosides were found present in all the extracts of tuber. Only ethanol and aqueous extracts of tuber were tested positive for the presence of saponins. All the extracts of bulbil showed presence of saponins. Tannins were found present in all the extracts except petroleum ether and chloroform extracts of both parts. It was observed that methanol, ethanol and aqueous extracts of these plant parts showed better results in terms of extraction of phytoconstituents.

Table 1. Qualitative analysis of various solvent extracts of bulbils of $D$. bulbifera $\mathrm{L}$.

\begin{tabular}{lccccc}
\hline \multicolumn{1}{c}{ Extract } & Methanol & Ethanol & Aqueous & $\begin{array}{c}\text { Petroleum } \\
\text { ether }\end{array}$ & Chloroform \\
\hline Alkaloids & + & + & + & + & + \\
Carbohydrates & + & + & + & - & + \\
Flavonoids & + & + & + & + & + \\
Glycosides & + & + & - & - & + \\
Phenols & + & + & + & - & + \\
Proteins and amino acids & + & + & + & - & + \\
Saponins & + & + & + & + & + \\
Steroids & + & - & + & + & + \\
Tannins & + & + & + & - & - \\
Terpenoids & + & + & + & + & - \\
\hline \multicolumn{7}{r}{} & \multicolumn{7}{c}{ Present, - absent }
\end{tabular}

Table 2. Qualitative analysis of various solvent extracts of Dioscorea bulbifera L. tubers

\begin{tabular}{lccccc}
\hline \multicolumn{1}{c}{ Extract } & Methanol & Ethanol & Aqueous & $\begin{array}{c}\text { Petroleum } \\
\text { ether }\end{array}$ & Chloroform \\
\hline Alkaloids & + & + & + & + & + \\
Carbohydrates & + & + & + & - & + \\
Flavonoids & + & + & + & - & + \\
Glycosides & + & + & + & - & + \\
Phenols & + & + & + & - & + \\
Proteins and & + & + & + & - & + \\
amino acids & - & & & & - \\
Saponins & + & + & + & - & - \\
Steroids & + & + & - & + & - \\
Tannins & + & + & + & - & + \\
Terpenoids & + & + & - & - & + \\
\hline
\end{tabular}

\section{Nutritional assessment}

+ present, $-=$ absent

Chemical analysis showed that starch, total sugars, free sugars, proteins and lipids are found to be present in appreciable amounts (Table 3 \& Figure 1).

\section{Heavy metals and inorganic elements}

The present study showed that selected parts contained the nutritionally important elements such as $\mathrm{Ca}, \mathrm{Na}, \mathrm{K}, \mathrm{Mg}, \mathrm{Fe}, \mathrm{Zn}$ and $\mathrm{Cu}$. Potassium was found to be present in larger amount 
followed by $\mathrm{Mg}$ and $\mathrm{Ca}$ (Table 4 \& Figure 2). Sodium was found to be present in concentration of 1.123 and $1.98 \mathrm{mg} / \mathrm{g}$ in tuber and bulbil respectively. $\mathrm{Fe}, \mathrm{Zn}, \mathrm{Cu}$ and $\mathrm{Mn}$ were found to be in lesser quantities in both the selected parts. In tuber samples, concentration of Arsenic (As), Lead $(\mathrm{Pb})$ and mercury $(\mathrm{Hg})$ was $0.17,1.2$ and $0.008(\mu \mathrm{g} / \mathrm{g})$ respectively and in bulbil, concentration of $\mathrm{As}$ and $\mathrm{Pb}$ was 0.11 and $1.1(\mu \mathrm{g} / \mathrm{g})$ respectively. (Table $5 \&$ Figure 3 ) This concentration was found to be less than the permissible limit set by WHO, so these parts are devoid of heavy metal toxicity. The results also revealed the absence of mercury $(\mathrm{Hg})$ in bulbil and manganese $(\mathrm{Mn})$ in both plant parts. Nitrogen content in tuber and bulbil samples was recorded as $34.47 \pm 0.05(\%)$ and $32.85 \pm 0.16(\%)$ respectively.

Table 3. Nutrient composition of edible parts of D. Bulbifera, mg/g

\begin{tabular}{lll}
\hline & Bulbil & Tuber \\
\hline Starch & $5.0 .61 \pm 0.61$ & $7.5 \pm 1.2$ \\
Total Sugars & $43.6 \pm 0.42$ & $49.1 \pm 1.47$ \\
Free Sugars & $18.5 \pm 0.56$ & $19.3 \pm 0.47$ \\
Proteins & $23.8 \pm 0.89$ & $41.6 \pm 0.57$ \\
Lipids & $9.51 \pm 0.23$ & $3.5 \pm 0.2$ \\
\hline
\end{tabular}

Results are presented as Mean \pm SE

Table 4. Inorganic elements of bulbils and tubers of D. bulbifera L., $\mathrm{mg} / \mathrm{g}$

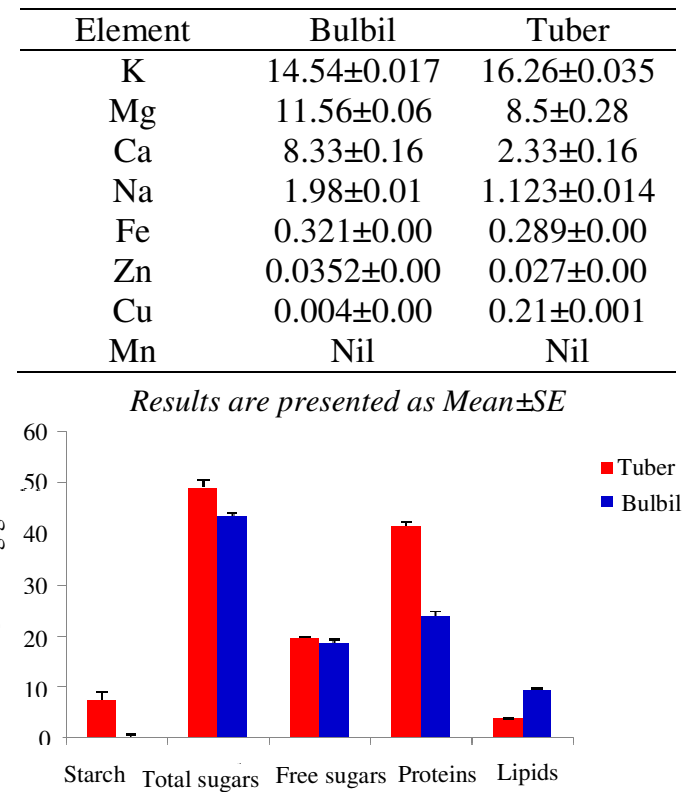

Figure 1. Nutrient composition of tubers and bulbils of $D$. bulbifera

Table 5. Heavy metal content of bulbils and tubers of $D$. bulbifera $\mathrm{L} ., \mu \mathrm{g} / \mathrm{g}$

\begin{tabular}{cll}
\hline Element & Bulbil & Tuber \\
\hline $\mathrm{As}$ & $0.11 \pm 0.005$ & $0.017 \pm 0.001$ \\
$\mathrm{~Pb}$ & $1.1 \pm 0.11$ & $1.2 \pm 0.11$ \\
$\mathrm{Hg}$ & BDL $^{*}$ & $0.008 \pm 0.00$ \\
\hline
\end{tabular}

$* B D L=$ Below detection level, Results are presented as Mean $\pm S E$ 


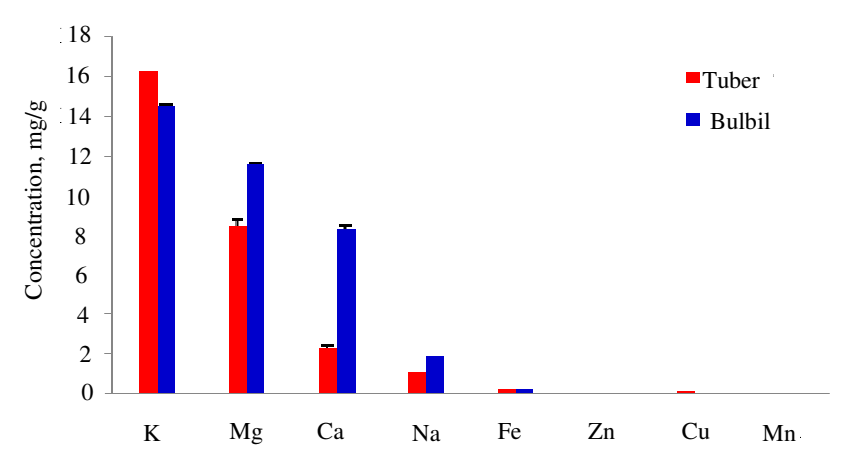

Figure 2. Essential mineral element composition of tubers and bulbils of $D$. bulbifera

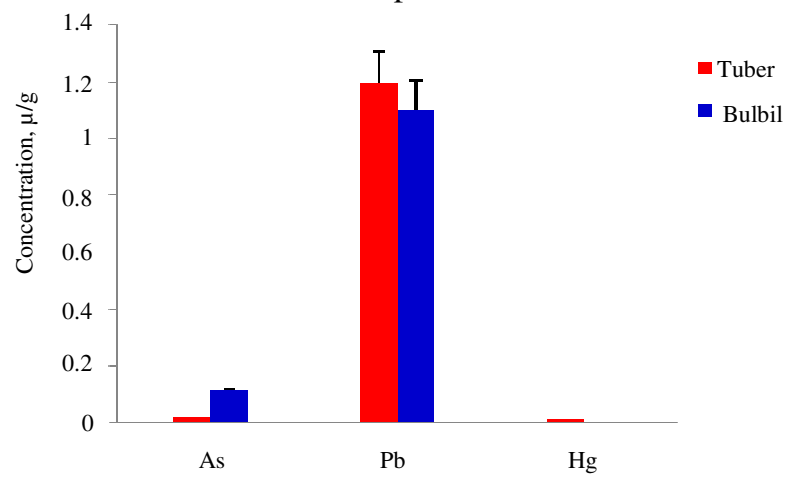

Figure 3. Toxic heavy metal composition of tubers and bulbils of D. bulbifera

\section{Conclusion}

Mineral element estimation of medicinal and edible plants is very important in identifying new sources of nutritionally important compounds. The mineral analysis of Dioscorea bulbifera revealed that it may act as a good source of diet as it contains good amounts of necessary mineral elements, fats, proteins and sugars essential for human health. From the present investigation, it can be concluded that all the levels of three potentially toxic heavy metals analyzed were quite below the permissible limits in both the plant parts analyzed. The implication of the present findings may be taken into consideration while dealing with this medicinal plant for human or animal consumption.

The results suggest that regular screening of raw plant materials is necessary to check the levels of these heavy metals in the plant parts and extracts before using them for consumption or herbal formulation.

It is therefore further advised that, medicinal plants used for human or veterinary use or for preparation of herbal products and standardized extracts should be collected from an unpolluted natural habitat.

\section{Acknowledgement}

Authors are highly thankful to Head, School of Studies in Botany for providing needed facilities. Authors are thankful to the Advanced Environmental Testing and Research Laboratory, New Delhi, India, for providing Atomic Absorption Spectroscopy (AAS) facility to carry out this work. 


\section{References}

1. Jawla S, Gupta A K, Singla R and Gupta V, J Chem Pharma Res, 2009, 1(1), 105-112.

2. Katiyar C, Kanjilal S, Gupta A and Katiyar S, AYU-An International Quarterly Journal of Research in Ayurveda, 2012, 33(1), 10-18.

3. Edeoga H O, Okwu D E and Mbaebie B O, J Med Aromatic Plant Sci., 2003, 25, 1010-1015.

4. $\quad$ Nickel E H, The Canadian Mineralogist, 1995, 33(3), 689-690.

5. Gopalan C, Sastri B V R and Balasubramanian S C, Indian Council of Medical Research, Hyderabad, India, 2004, 2-58.

6. WHO, Quality Control Guidelines for Medicinal Plant Materials (World Health Organization, Geneva), 1998, 1-111.

7. Rajurkar N S and Damame M M, Appl Radiat Isot., 1998, 49(7), 773-736; DOI:10.1016/S0969-8043(97)00296-0

8. Gupta D and Singh J, Phytochemistry, 1989, 28(3), 947-949; DOI:10.1016/00319422(89)80153-0

9. Ahmad S, Introduction to Pharmacognosy, I.K. International Publishing House Pvt. Ltd., New Delhi, 2012, 382-386.

10. Kokate C K, Purohit A P and Gokhale S B, Pharmacognosy, Nirali Prakashan, Pune, 2003, 1-62.

11. Prajapati N D, Purohit S S, Sharma A K and Kumar T, A Hand Book of Medicinal Plants, Agrobios Jodhpur, 2003, 92.

12. AOAC, Methods of Analysis of Association of Official Analytical Chemists $\left(16^{\text {th }}\right.$ Ed.), Washington, D.C., 1997, 1, 600-792.

13. AOAC, 2005, AOAC Official methods of analysis $\left(16^{\text {th }}\right.$ Ed.), Association of Official Analytical Chemists, Washington, DC.

14. Soylak M, Tuzen M, Narin I and Hayati sari, J Food Drug Anal., 2004, 12(3), 254-258.

15. Pohl P, Dzimitrowicz A, Jedryczko D, Szymczycha-Madeja A, Welna M and Jamroz P, J Pharm Biomed Anal, 2016, 130, 326-335; DOI:10.1016/j.jpba.2016.01.042 